\title{
INTERNATIONAL EXPERIENCE OF DEVELOPMENT AND SUPPORT OF ENTREPRENEURIAL ACTIVITY OF INCLUSIVE TOURISM
}

\author{
Marta Barna', Iryna Tuchkovska²
}

\begin{abstract}
The article considers the state of international tourism for people with disabilities. It has been studied that inclusive tourism area has great potential for development, as more than $15 \%$ of the world's population can be defined as inclusive tourists. The volume of inclusive tourism market development is constantly increasing. Taking into account the world experience of development of "tourism for all" and analysis of statistics on the number of people with disabilities and socially disadvantaged people, the prospects for the development of the inclusive tourism market are determined, which is especially important given its social significance. Therefore, it has been expedient to analyze the prospects of creating an effective system of inclusive tourism.

The purpose of the article is to determine the prospects for the formation of an effective system of public administration for the development of inclusive tourism on the basis of international experience in supporting the entrepreneurial activity of inclusive tourism. The authors propose a system of integrated approach to ensure effective public policy in shaping the conditions for the development of inclusive tourism and creating a barrier-free environment for tourism destinations. Harmonization of the mechanisms for improving the effectiveness of public policy in the field of inclusive tourism requires the development of an organizational mechanism for implementing the concepts of "tourism for all" with the identification of practical aspects of its implementation in accordance with international norms and standards.

Given the limited state funding for tourism in Ukraine, the development of inclusive tourism cannot be highly efficient, which is primarily due to the social direction of the area.

The international documents and Ukrainian normative acts and laws regulating tourist activity for people with disabilities are analyzed and studied.

To create an effective system of social protection for all categories of the population, including people with disabilities, it is necessary to take into account the experience of foreign countries, where a resembling system has been operating quite successfully for a long time. From this point of view, firstly, it is necessary to consider the social protection systems that have been introduced in the countries of the European Union, where the disabilities rights movement has been launched. In the countries of the European Union, social policy and the participation of social partners in its formation have undergone significant transformations, and a fundamentally new supranational and suprastate course of social protection and welfare of citizens has emerged. As a country aspiring to join the European Union, Ukraine must take into account the best foreign experience of the world's leading countries in the field of state policy to support persons with disabilities and its implementation.

The European and world experience of adaptation of the tourism industry for people with disabilities (on the example of Slovenia, Israel, Spain and the USA) is analyzed. The problems that hinder the development of international tourism for people with disabilities in Ukraine and measures to solve them are identified.
\end{abstract}

Key words: person with a disability, inclusive tourism, international tourism, world experience, state tourism agency, state support mechanisms.

JEL Classification: F29, I31, L83, O51, O52

Corresponding author:

${ }^{1}$ Lviv University of Trade and Economics, Ukraine.

E-mail:martabarna@ukr.net

ORCID: https://orcid.org/0000-0001-5248-9774

ResearcherID: G-9493-2019

${ }^{2}$ Lviv University of Trade and Economics, Ukraine.

E-mail: irinatuckovska@gmail.com

ORCID: https://orcid.org/0000-0001-6719-2981

ResearcherID: E-9848-2019 


\section{Introduction}

The tourism industry has significant potential to increase key performance indicators. Global trends indicate a strong development of the industry, statistics from the World Tourism Organization show steady results in the growth of tourism flows and income from tourism. Tourism is a multiplier industry that provides high returns with low investment. Therefore, one of the key characteristics of the development of the tourism industry will be high competition, which contributes to the further development of tourism, improvement of the quality of tourism services. Recent trends in tourism development indicate the attention of tourism entities to the modernization of inclusive tourism infrastructure, the allocation of inclusive tourism in a particular type of tourist activity, and promotion of its further improvement.

Since inclusive tourism has emerged as one of the branches of social tourism, it is appropriate to highlight thekeyrole of the statein ensuringitsfurther development in order to ensure the state's implementation of social guarantees as an important element of nationhood and civil society. Thus, the article is devoted to the topical issue of determining the role of public policy in creating favorable conditions for the development of inclusive tourism based on international experience.

The international tourism market has undergone many changes in recent years: the segment has attracted people with disabilities, actively creating all the necessary conditions for them and developing special programs of tourism services, taking into account their needs and capabilities.

This type of tourism has many titles, for example, "inclusive tourism", "social tourism", "barrier-free tourism", "paratourism”, etc. They all mean the availability of travel for people with disabilities, because this activity integrates this activity integrates this category of population into society, gives them the opportunity to develop, feel healthy, specifically emotionally, and be on par with others.

Inclusive tourism in Ukraine is a fairly new concept and activity. This is due to a number of problems, both social and economic. At present, there are organizations and associations of people with disabilities that provide medical and rehabilitation services throughout the country. Certainly, they arrange entertainment activities, as well as excursions, but usually not over long distances due to the underdeveloped infrastructure, which is not designed for people with disabilities.

\section{Methodology of research}

Worldwide, more than one billion people (23\% of the population) suffer from various forms of disability. According to a research conducted by the World Health Organization, 785 million people aged 15 and older live with disabilities, of whom 110 million suffer from severe disorders. Among children aged 0 to 14, these figures are 95 million and 13 million, respectively (International Disability Statistics, 2018).

In Ukraine, more than 2.6 million people have the status of a person with a disability, which is $6.25 \%$ of the total population. The number of people in this category is growing every year due to many factors, such as environment, living and working conditions (Trunina, Sosnovska, 2019).

Tourism for people with disabilities, including the international one, is a fairly new phenomenon, which has a low level of study and publicity, but nevertheless, it is a necessary type of tourism in every country. Inclusive tourism is developing rapidly today. Experts in this field estimate that 2.5 million people with disabilities travel regularly.

The development of inclusive tourism is closely linked to the demand for this type of service. Statistics show that in the future such demand will grow, so inclusive tourism has significant potential to increase the flow of tourists (Ugodnikova, 2019). According to statistics, more than 2 million people with disabilities live in Ukraine nowadays (Official website of ETAN, 2019). There is a tendency to aging of population, i.e. more people move to the categories in need of social protection and inclusive conditions for tourism development. So, inclusive tourism is becoming increasingly important among the population of different countries.

There are several definitions of "a person with a disability", "disability" in the world. Each state has its own criteria, according to which it grants a person the status of a person with a disability. There are just some of the reasons why disability indicators are difficult to measure and define globally.

Understanding the potential of people with disabilities has initiated the emergence of different concepts of their inclusion in the normal life of society. In the recent history of social policy in the United States and Europe, several approaches have been developed: integration (from Latin: Integratio - connection, restoration), inclusion. The same trends can be traced in the domestic social system.

Different countries have individual interpretations of the concept of "disability". For example, if a person has a status of a person with a disability in the United States, it does not mean that his or her status will be recognized in China or Germany.

D. Say determines that this is to some extent due to the fact that the world has not reached a consensus and understanding of what disability is. Fundamentally different terms can be used to denote people with intellectual disabilities, even in countries where a similar language is used (Say, 2013).

There are many definitions of tourism for the people with disabilities. After analyzing the latest research and publications, we highlight the following: "inclusive tourism", "accessible tourism", "tourism for all”, "barrier- 


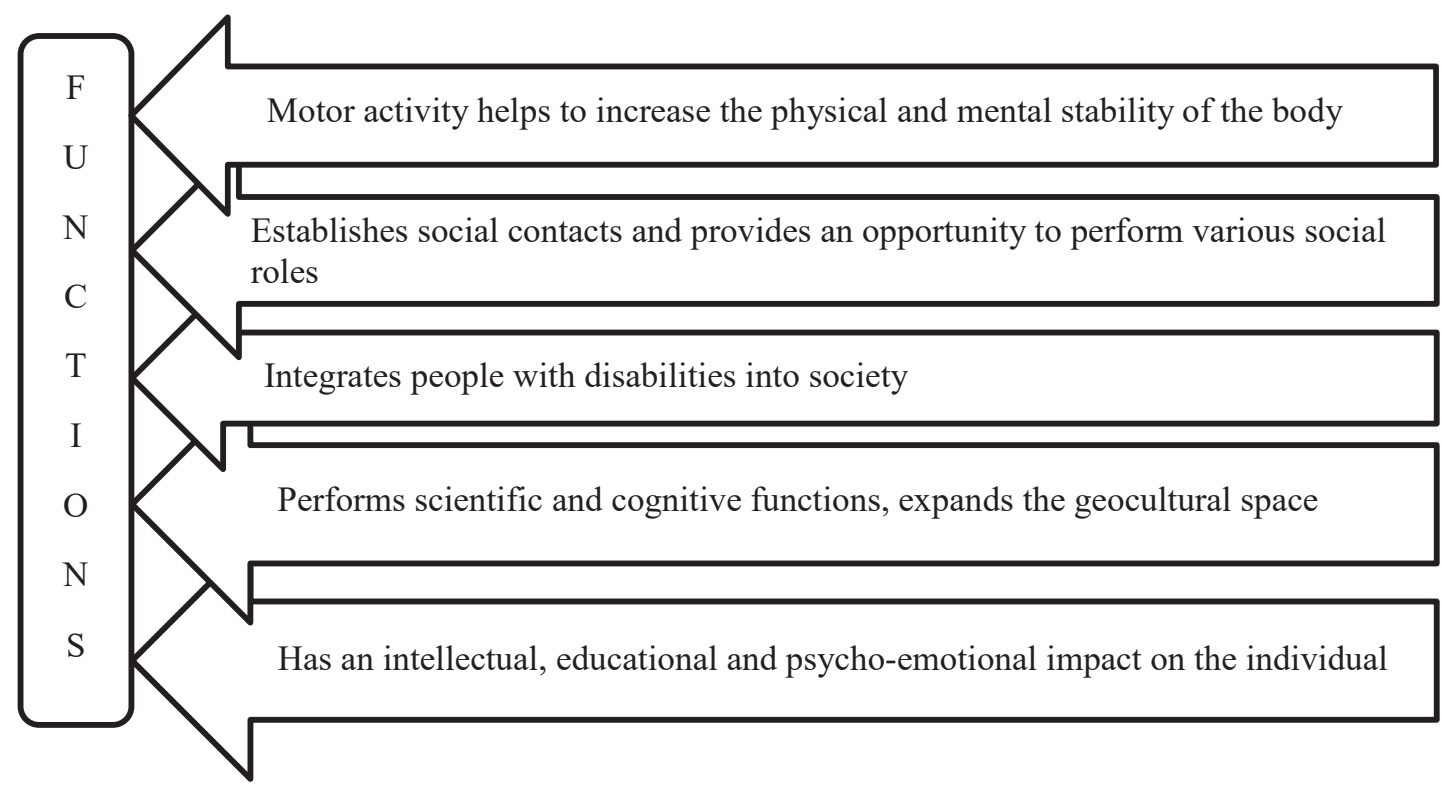

Figure 1. Functions of inclusive tourism

Source: based on (Bulousova, 2017)

free tourism", "tourism for people with disabilities", "social tourism". Their special feature is the ability of persons with disabilities to travel to various tourism facilities and institutions with an accessible and adapted infrastructure for this category of the population. The functions performed by tourism for people with disabilities are shown in Figure 1.

According to international documents in the field of tourism, inclusive tourism is defined as a recreational type of tourism for people with special needs. In 1991, the UNWTO General Assembly defined the concept of inclusive tourism, that is a tourism for all in the Concept "Creating Opportunities for Tourism for People with Disabilities in the 1990s".

The system of national legislation prescribes only the concept of rehabilitation and provision of rehabilitation services to persons with disabilities, which is directly related to recreational and tourist activities, but does not fully cover the range of services and opportunities for the use of tourism.

The term "accessible tourism for all" was enshrined in 2009 at the 18th session of the UNWTO General Assembly in Astana, Kazakhstan, in the "Declaration on the Facilitation of Tourist Travel", which called on UNWTO Member States to make their tourist facilities and institutions accessible to people with disabilities, publish clear and detailed information on the reception services available to them and on the problems they may face when traveling (Committee of Ministers of the Council of Europe, 1992; Trunina, Sosnovska, 2019).

In view of the above, it should be noted that today the activities of all national institutions, including public authorities, public associations, etc., should be aimed at creating conditions in which persons with disabilities can lead independent lives and take an active part in all its aspects.

\section{Results and discussion}

\subsection{International experience in supporting and developing inclusive tourism}

There are processes of active institutionalization in the field of tourism for people with disabilities. This is evidenced by the emergence of the international tourism organization SATH, which holds annual congresses, publishes a monthly publication, cooperates with governments. SATH includes non-profit and public organizations from different countries, as well as organizations from various fields of tourism business. SATH is headquartered in New York City, USA, and the number of SATH members is growing steadily. Today, SATH is a member of the World Tourism Organization, which testifies to the integration of tourism for people with disabilities into the global tourism system (International organizing tourism for people with disabilities).

The following elements have been included in the structural components of inclusive tourism by international organizations (Official website of ETAN): - ensuring the implementation of the concepts of barrier-free architecture by creating an inclusive tourism area, inclusive infrastructure, construction of real estate in accordance with the norms and standards of inclusiveness;

- accessibility of all types of transport for use by people with disabilities;

- providing quality services to accompany tourists by training staff in appropriate qualifications; 
- inclusiveness of cultural and entertainment facilities;

- inclusive component of marketing activities, in particular the formation of comfortable booking conditions, presentation of tourist offers, etc.

At the core of the Concept of Inclusive Tourism, which involves travelling around the world, is a universal design, seven principles of which were formulated and implemented more than 30 years ago under the guidance of wheelchair architect Ron Mace and colleagues at North Carolina State University. These principles underlie social rehabilitation, including the development of an inclusive tourism system in the European, Asian and American tourism regions (Mabbett, Bolderson, 2002).

As an example of the organization of international tourism and accessibility of travel for people with disabilities have been taken several countries: Slovenia, Israel, Spain, the USA.

In recent years, Slovenia's tourism infrastructure has been adapted to meet the needs of people with disabilities. At the entrance to public buildings and sights there is a separate parking area for people with disabilities. Almost all shopping centers, public buildings, tourist places are equipped with toilets for people with disabilities. Sidewalks of special configuration have been built in many Slovenian cities.

More and more ATMs are being installed at a lower level than usual for more convenient access for people with visual impairments using Braille. Among the Slovenian cities that improve accessibility for people with disabilities, Ljubljana, Maribor, Ajdovščina and others should be emphasized. People with disabilities are in most cases entitled to free tourist attractions or discounts.

The State Tourism Corporation of Israel, the executive body of the Ministry of Tourism of Israel, has initiated a number of projects in terms of infrastructure, the purpose of which is to make people with disabilities able to visit numerous tourist sites in the country, encourage them to travel in Israel. New facilities are being built, and old ones are being reconstructed to suit their needs. For example, Masada, a rock with a legendary fortification near the Dead Sea, has become accessible to people with disabilities up to the very top. Part of this most important tourist facility has been arranged so that people with visual impairments can perceive ancient stones to the touch (International experience, 2020).

Spain is also developing rapidly to meet the needs of inclusive tourists. Public transport and the central streets of Barcelona are adapted to their needs. The Spanish Tourism Board pays great attention to affordable tourism, and the authorities are also making considerable efforts to involve such people in a full active life. The tourism infrastructure is specially adapted for people with disabilities, specialized catalogs are published, events are held, including the Paralympic Games.
The central streets of the cities are equipped with ramps, all buses are adapted for this category of people, the hotels have special rooms convenient for them. Each new metro station has special equipment for people with disabilities.

In 2019, a special site "Accessible Tourism" was created. It contains all the information about the relevant trips to Catalonia. On the site you can find detailed information about 19 tourist destinations, where the necessary conditions are created for the reception of people with disabilities.

\subsection{Determination of state support for entrepreneurial activity for inclusive tourism in Ukraine}

Currently, in the world of social policy, one of the most important activities is the integration and social adaptation of people with disabilities, the number of which in Ukraine at the beginning of 2018 has been about 2.6 million, almost $80 \%$ of them have been of working age. Children account a significant share in the structure of people with disabilities: more than 167 thousand ( $2 \%$ of the total child population).

However, according to international classifications, this number of people with disabilities is much higher, as disability can be temporary, not necessarily congenital or acquired (Vojtovska, 2018).

Over the last ten years, Ukraine has undergone reforms in almost all areas of social security and safety and health protection. At the present stage, Ukraine is trying to create an effective system of social protection for all categories of the population, including people with disabilities. In the process of its development the experience of foreign countries, where such a system has been operating quite successfully for a long time, should be taken into account. From this point of view, the system of social protection implemented in the countries of the European Union, where the disability rights movement has been launched, may be of concern, especially given Ukraine's interest in the EU membership.

In the countries of the European Union, social policy and the participation of social partners in its formation have undergone not only a significant transformation, but also a fundamentally new supranational and suprastate course of social protection and welfare (The official website of the World Tourism Organization).

In Ukraine, the provision of conditions for the development of inclusive tourism is defined in the following legal documents: the Constitution of Ukraine; Law of Ukraine "On State Social Standards and State Social Guarantees"; Law of Ukraine "On the Basis of Social Protection of the People with Disabilities in Ukraine"; Law of Ukraine "On Social Services"; Law of Ukraine "On Rehabilitation of the Disabled in Ukraine"; "Convention on the Rights of Persons with Disabilities”. 
These regulations define the main provisions of the state social policy concerning the creation of comfortable living conditions and social security for persons with disabilities. However, there is no separate normative legal act or provisions in the developed documents that would determine the mechanisms of implementation of the functions of state management of the development of an inclusive tourist environment.

The Law of Ukraine "On Tourism", which is the main legal document regulating tourism, does not define the concept of inclusive tourism (Law of Ukraine "On Tourism", 2017).

In Ukraine, the quality of life of people with disabilities, as a rule, is lower than of the rest of the population, which is due to the following: lack of humanism and mercy towards people with special needs in our society; underdevelopment and unadaptability of social infrastructure of cities and rural settlements, taking into account the basic needs of people with disabilities; low level of material security and social services, lack of flexibility; low quality or lack of technical means and devices necessary for the service, movement and work of people with disabilities; the presence of significant difficulties in obtaining professional, especially higher education, in meeting spiritual needs (Bajda, 2011).

Recommendation 1185 to the Rehabilitation Programs of the 44th Session of the Parliamentary Assembly of the Council of Europe dated May 5, 1992 defines disability as a limitation due to physical, psychological, sensory, social, cultural, legislative and other barriers that prevent a person with a disability from being integrated into society and participate in the life of the family or society on the same grounds as other members of society (Ugodnikova, 2019).

Thus, disability is a social phenomenon that no society can avoid, and therefore each state in accordance with its level of development, priorities and opportunities forms a social and economic policy for people with physical and (or) mental disabilities.

Sanatorium and resort business for people with special needs in Ukraine is based on the current Law of Ukraine "On Resorts", adopted on October 5, 2000 (The official website of the World Tourism Organization), and the relevant legal framework governing the activities of this area, ensuring the availability of sanatorium treatment for all citizens, and especially for people with disabilities, children, patients with tuberculosis, etc., economical and rational use of natural healing resources and their protection.

The tourism markets for people with special needs today are the first state sanatorium-resort zone. On December 16, 2009, the Verkhovna Rada adopted the Law of Ukraine "On Ratification of the Convention on the Rights of Persons with Disabilities and its Optional Protocol" (State Employment Service, 2019). The Convention on the Rights of Persons with Disabilities stipulates that member states undertake to ensure and promote the full realization of all human rights and fundamental freedoms by all persons with special disabilities without any discrimination on grounds of disability. To this end, member states are under obligation to take all appropriate measures to eliminate any discrimination against persons with disabilities, and to promote the availability and use of new technologies, including information and communication technologies, mobility aids, equipment and assistive devices convenient for people with disabilities, giving priority to low-cost technologies.

Thus, inclusive tourism for people with disabilities is a modern type of tourism that allows any person to participate, regardless of his or her physical capabilities, taking into account the peculiarities of his or her physical and psychological condition and it is considered primarily as a powerful means of active rehabilitation, which structurally includes medical, psychological, pedagogical, physical, professional, labor, physical culture and sports, and social activities.

\subsection{Prospects for the development of inclusive tourism in Ukraine}

Analyzing the prospects for the development of tourism for people with disabilities in Ukraine, we consider the following measures to increase the availability of infrastructure for such tourists:

1. Improvement of the legal and regulatory framework for inclusive rehabilitation and social tourism, consolidating its full functioning. The implementation of this direction will testify to the high social orientation of the state, its care and concern for citizens with disabilities. Study of the conditions of free access to tourist infrastructure and tourist attractions for people with disabilities.

2. Arrangement of tourist facilities with ramps, call buttons and special markings.

3. Information support of projects of public organizations and dissemination of information about opportunities for barrier-free recreation on the territory of Ukraine.

4. Improving inclusive tourism products such as online tours, development of farmsteads in rural areas.

At the regional level, we offer the following practical measures:

- publication and dissemination of methodological recommendations on the arrangement of tourist infrastructure facilities in compliance with the requirements and taking into account the needs of persons with disabilities and the staff of tourist institutions, guides and accompanying persons;

- assessment of compliance of tourist attractive regional objects with the needs of persons with disabilities; - selection of tourist facilities and attractions in each area, the most interesting and suitable for tourism, recreation of people with disabilities. 
Thus, today in Ukraine, tourism for people with disabilities is in great demand, but it is developing mainly due to the ambitions of caring people. Therefore, the most important tasks of the state should be the following:

- social adaptation and socialization of persons with disabilities in society, increasing their rehabilitation potential and quality of life, including with the help of tourism; expansion at the legislative level (in particular, in the Law of Ukraine "On Tourism"), the priority areas of state policy in the field of specialized tourism markets for people with special needs;

- increasing the profitability of tourism for people with disabilities, encouraging national and foreign investment in the development of this tourism industry, attracting charities and other organizations, sponsors, creating new jobs;

- development of tourism for people with disabilities in rural areas, its combination with ecological (green) tourism; creation of favorable conditions for the development of tourism markets for people with special needs by simplifying tax, customs, currency, border and other regulations; expanding international cooperation in the field of tourism for people with disabilities.

Ukraine, which describes itself as a welfare state, needs specialized tourism markets for people with special needs as a social phenomenon and as a form of rehabilitation and integration of people with disabilities into society, for social adaptation and socialization of these people, to increase their rehabilitation potential and quality of life.

\section{Conclusions}

1. It is investigated that inclusive tourism in the conditions of socialization of economy is a modern "panacea", which will allow to include in tourist activity any person, irrespective of his or her physical possibilities, taking into account features of his or her physical and psychological condition. Inclusive tourism in terms of socialization of the economy is seen as a powerful tool for active rehabilitation, which structurally includes medical, psychological, pedagogical, physical, professional, labor, physical culture and sports, and social activities, which can significantly affect the development of society. Meeting public needs will bring the economy to a new level of competitiveness.

2. In the studied countries (Slovenia, Israel, Spain and the USA) there is a well-developed infrastructure that allows people with disabilities to travel with minimal inconvenience, which cannot be applied to Ukraine. There has been identified a number of factors that complicate the development of international tourism for people with disabilities in Ukraine. To solve the above problems, the following measures can be proposed: a) development of a system of information support on tourism and excursion services that are accessible to people with disabilities;

b) support of tourist activity of the low-income population, encouragement of travel together with the person accompanying it, by introduction of system of discounts; c) adoption of a state program for the development of social tourism, accessible to all;

d) creation of a separate state department to assist in processing documents and obtaining visas for persons with disabilities;

e) creation of a special transport infrastructure for inclusive tourism, taking into account re-equipment of vehicles, construction and improvement of roads, simplification of the ticket sales system;

f) payment for accommodation in hotel establishments in the amount of $50 \%$ of the cost, due to the adopted state social programs.

We believe that many Ukrainian regions are ambitious for the development of inclusive tourism in Ukraine, have high economic, social and innovative potential. But on the basis of high economic development, we see a low level of integration and socialization of people with disabilities to a fulfilling life. Accessibility, barrier-free design and employment remain among the main problems of regional socialization of people with disabilities. The economic quality of development (efficiency, profitability) of regions should be combined with the social quality of service provision (high level of education, health care, level of well-being and life expectancy, satisfaction with the nature and working conditions, etc.).

It is analyzed that the number of people with disabilities in Ukraine is increasing every year, only abot $5 \%$ of the total number of them travel. This is due to a number of reasons: lack of inclusive tourism; websites are not available, or only partially accessible; lack of adapted vehicles, hotel rooms; lack of professional staff capable of solving accessibility problems; lack of reliable information on the level of specific problems that a disabled person may face; lack of available restaurants, bars, and other facilities, adapted toilets; streets and sidewalks are not accessible.

It is substantiated that the solution of these problems is possible by making appropriate amendments to the Laws of Ukraine "On Rehabilitation of the Disabled in Ukraine", "On Social Services" and "On Tourism”, by consolidating the full functioning of inclusive tourism as a type of social and physical rehabilitation of people with disabilities.

At the regional level, it is necessary to conduct a series of regional training webinars "Improvement of inclusive tourism infrastructure as a guarantee of effective economic development of the region", involving specialists in this field.

The implementation of the proposed measures will expand the possibility for travel companies to use and provide inclusive tourism services, such as online tours, the development of farmsteads in rural areas. 


\section{References:}

Bajda, L., Krasiukova-Ens, O., Burov, S., Azin, V., Hrybal's'kyj, Ya., \& Najda, Yu. (2011). Invalidnist' ta suspil'stvo [Invalidity and society]. Kyiv.

Bulousova, N. V. (2017). Providing inclusive tourism in the socially-reabilitated system of Ukraine. Molodiy impressions.

Chajkovskyj, M. Ye. (2016). Theory and practice of social-pedagogical work with young people with special needs in conditions of inclusive educational space. Extended abstract of doctor's thesis. Starobilsk.

Committee of Ministers of the Council of Europe (1992). Recommendations to Member States "On a consistent policy for people with disabilities”. Available at: http://zakon2.rada.gov.ua/laws/show/994_128 (accessed 25 July 2020).

Galitsky, O. M., \& Grishova, R. V. (2019). Svitovy notice of the implementation of the state policy of the adoption of the innovations and their implementation in Ukraine. Investments: practice and dosvid, vol. 6, pp. $122-127$.

European Commission (2019). Mutual Information System on Social Protection of European Commission. Available at: http://ec.europa.eu/socia (accessed 25 February 2019).

International Disability Statistics 2016. Available at: http://specialbank.ru/2016/12/23/stats_world (accessed 25 July 2020).

International experience in organizing tourism for people with disabilities. Available at: https://studbooks.net/ $693903 /$ turizm/mezhdunarodnyy_opyt_organizatsii_turizma_lyudey_ogranichennymi_vozmozhnostya (accessed 25 July 2020).

International Labor Organization (2020). Available at: http://www.un.org/en/aboutun/structure/index.shtml (accessed 25 July 2020).

Law of Ukraine "On Tourism" (2017). Available at: https://zakon.rada.gov.ua/laws/show/324/95-\%D0\% B2\%D1\%80 (accessed 25 July 2020).

Leidner, R. (2008). Tourism accessible for all in Europe. Tourism Review. Ethical: Barrier Free Tourism, April.

Mabbett, D., \& Bolderson, H. (2002). Definition of disability in Europe. A comparative analysis, European Commission: Employment \& social affairs, Brussels, Belgium.

Naumenko, L. Yu., et al. (2017). Inclusive tourism as a type of rehabilitation: occasional consumerism. Ukrainian Newsletter of Medical and Social Expertise, vol. 2, pp. 23-26.

Official website of ETAN International Organization. Available at: http://www.etan.org/ (accessed 25 July 2020). Romanova, A. A. (2017). See tourism and its classification in the context of current trends in the development of tourism. Economics and Region, vol. 4(65), pp. 13-19.

Say, D. (2013). Attitudes towards people with disabilities: People's Republic of China, Japan and India. Sociology: theory, methods, marketing, vol. 1, pp. 117-130.

State Employment Service (2019). Available at: http://www.dcz.gov.ua/-control/uk/index (accessed 25 July 2020).

Svarnyk, M. G., Grybalskyj, Ya. I. et al. (2015). Guide for active recreation and tourism for the disabled. Lviv: Tovarystvo "Zelenyj Hrest".

The official website of the World Tourism Organization. Available at: http://www.unwto.org/ (accessed 25 July 2020).

Trunina, I. M., \& Sosnovska, Y. R. (2019). Stand of international tourism for people with indispensability in Ukraine. Modern Economics, vol. 15, pp. 191-195. Available at: https://modecon.mnau.edu.ua (accessed 25 July 2020).

Ugodnikova, O. (2019). Prospects for the implementation of state policy in the development of inclusive tourism. Public Administartion Aspects, vol. 7(1-2), pp. 37-42.

Vojtovska, A. I. (2018). Features of Inclusive Tourism. Available at: http://tourlib.net/statti_ukr/vojtovska.htm (accessed 25 July 2020).

Zaiukov, I. V., \& Stakhov, O. I. (2015). Problems and prospects of employment of disabled people in Ukraine. Visnyk Berdians'koho universytetu menedzh-mentu i biznesu, vol. 1(29), pp. 127-132. 